\title{
Compost and Biochar Characteristics Test of Some Animal Manure Waste
}

\author{
I Dewa Nyoman Sudita ${ }^{\mathrm{a}, 1}$, Yohanes Parlindungan Situmeang ${ }^{\mathrm{b}, 2}$, Made Suarta ${ }^{\mathrm{b}}$ \\ ${ }^{a}$ Study Program of Animal Science, Faculty of Agriculture, Warmadewa University. Denpasar-Bali, Indonesia \\ ${ }^{b}$ Study Program of Agrotechnology, Faculty of Agriculture, Warmadewa University, Denpasar-Bali, Indonesia

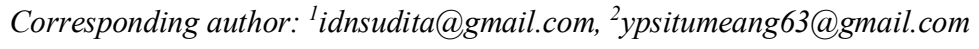

\begin{abstract}
This study aims to determine the quality of compost and biochar from some animal manure in improving soil properties and fruit yields of chili plants. This research was conducted in a greenhouse, with nesting experiments using a random block design. The treatment composition consisted of 6 types of fertilizer (cow compost, goat compost, chicken compost, cow biochar, goat biochar, chicken biochar), and three levels of fertilizer doses $\left(5,10\right.$, and 15 tons ha $\left.^{-1}\right)$ and one treatment control. The results showed differences in fertilizer types differed significantly for $\mathbf{N}$-total soil and weight of red chili and were significantly different from $P$-available in the soil. While the difference in compost fertilizer dose has a significant effect on P-available and K-available soil, cow dung compost has the lowest effect on soil properties. The number and weight of fresh red chili per plant, while compost goat manure tends to be highest. Biochar from chicken droppings and doses significantly influenced the total $N$, the highest available $P$ and the lowest $C / N$, and the amount and weight of fresh red chili. From this study, it can be concluded that the type of raw material for livestock manure for compost and biochar affects soil properties and red chili production, where compost and biochar from goats and chicken manure are better than cow dung. This research's implication is the type of animal feed ingredients affecting the face of livestock and determining the quality of compost and biochar.
\end{abstract}

Keywords-Compost; biochar; livestock faeces; chili.

Manuscript received 15 Mar. 2020; revised 12 Oct. 2020; accepted 30 Nov. 2020. Date of publication 28 Feb. 2021. IJASEIT is licensed under a Creative Commons Attribution-Share Alike 4.0 International License.

\section{INTRODUCTION}

Farmers have used animal waste for a long time as a manure source (organic fertilizer) in agricultural systems for various types of plants. As time goes by entering the green revolution in agriculture to increase farm products' productivity, the use of synthetic inorganic fertilizers in Indonesia is out of control. Extensive use of chemical fertilizers raises serious insurance problems such as environmental pollution, development of pest resistance and decreased food safety [1]. As a result, there has been a change in the ecosystem of agricultural land due to the use of inorganic fertilizers and other chemicals characterized by declining soil quality and loss of genetic diversity on agricultural land. Besides, there are adverse impacts on the agricultural land condition, especially the soil's acidity and physical properties. Therefore, various government programs currently, especially in Bali and farmers' awareness, can effectively reuse organic fertilizer in their agricultural business [2].
Organic fertilizers are biological products that mostly contain nutrients in organic compounds such as amino acids, proteins, and carbohydrates. Organic material that can be used as a source of organic fertilizer can come from agricultural and non-agricultural waste/products (municipal waste and industrial waste) and livestock manure [3]. Organic matter has a positive effect on the activity of various hydrolase enzymes caused by an increase in microbial biomass [4]. Organic fertilizer significantly increases the yield and quality of vegetables, but with an improper application, it can cause serious environmental risks such as nitrate pollution, the highest efficiency of $\mathrm{N}$ use with the smallest nitrate enrichment in the soil [5]. Manure, compost, and biochar are several types that are included as solid organic fertilizer, each of which has different properties. Manure is all animal waste products that can be used to improve nutrition, improve physical properties, and soil biology [6]. Some types of manure as compost and biochar material are cow, goat, and chicken manure. 
These animal faeces have different properties and qualities in their nutritional content, which are near related to the type of feed and their digestive system. The composition of nutrients in each animal waste varies depending on the amount and type of feed, in general, is much lower than chemical fertilizers. The low availability of nutrients in manure is caused by N,P and other elements found in the form of complex organic protein compounds or humic acid compounds and lignin that are difficult to decompose [7]. Cows and goats as ruminants that ruminate most of their food (basal feed) from forages that contain lots of crude fibre (cellulose), in the digestive system are assisted by microbes contained in the rumen and on the large stomach (caecum and large intestine). Whereas in chicken, most of the food comes from grains and concentrates, so the faeces are still rich in protein that is not fully digested in the digestive tract. Therefore, the quality of manure and compost from animal manure will be different, which is determined by the $\mathrm{C} / \mathrm{N}$ ratio. Besides containing nutrients needed by plants, livestock manure also contains humic acid, fulvic acid, hormones and others which stimulate plant growth and increase nutrient absorption [8], because each type of livestock manure contains fulvic acid, cation exchange capacity, $\mathrm{C} / \mathrm{N}$, and $\mathrm{K}$ are different [9].

Composting is defined as a biological decomposition process to achieve stable organic material, with heat production, the final compost product will produce a stable, free of pathogens and weed seeds, reduce odor and easier to apply in the field. Composting can increase the availability of nutrients for plants, especially $\mathrm{N}, \mathrm{P}, \mathrm{K}, \mathrm{Ca}$, and $\mathrm{Mg}$ nutrients, and reduce the $\mathrm{C} / \mathrm{N}$ ratio and moisture content. The $\mathrm{C} / \mathrm{N}$ ratio determines one good compost quality indicator because a higher $\mathrm{C} / \mathrm{N}$ ratio causes a high level of $\mathrm{C}$, which will suppress plant growth. After all, microbial decomposers will use $\mathrm{N}$ to decompose organic matter so that plants lack N. C/N ratio high in cow dung caused by highfiber feed such as cellulose and water content, while goat manure due to grains is rather difficult to break down physically in the decomposition process. Livestock manure that has been processed into compost will reduce the $\mathrm{C} / \mathrm{N}$ ratio in cattle (16.8), goat manure (11.3), and chicken manure (10.8) [6]. The treatment of organic fertilizer significantly reduces the content of $\mathrm{Cu}, \mathrm{Pb}$, and $\mathrm{Cd}$ in the soil and can substantially increase the tea leaves' amino acid content and soil $\mathrm{pH}$ [10]. It is recommended that the integration of conventional organic compost with inorganic NP 50\%: 50\% increase in wheat production [11]. In the composting process, there will be three stages: the decomposition and sanitation stage, the conversion stage, and the synthetic (maturation) stage [12]. During the composting process, there will be an exothermic reaction so that there will be heat due to the release of energy, while in the aerobic process the energy released (464-674 kcal moles of glucose-1) compared to anaerobic processes is only 25 kcal moles of glucose-1. The use of compost as a soil conditioner can increase soil organic matter content, thereby maintaining and improving soil fertility. General characteristics of compost include: 1) containing nutrients in types and amounts that vary depending on the origin, 2) provide a slow release of nutrients, and 3 ) have the primary function of improving soil fertility and health [7]. Adding compost to the soil can increase the value of cation exchange capacity [8].

Livestock manure is processed into compost and can be processed into biochar through incomplete combustion processes that can function as soil amelioration. Biochar is the result of incomplete combustion of agricultural biomass from crop and livestock waste. Biochar can increase organic $\mathrm{C}$, respiration, and aggregation and improve water and air circulation in the soil and stimulate root growth. Also, the addition of biochar to the soil increases the availability of phosphorus, total $\mathrm{N}$ and soil cation exchange capacity which ultimately increases yield because it can reduce the risk of leaching of potassium and N-NH4 nutrients [13], on the other hand, biochar activated charcoal as a whole can improve physical, chemical, biological, and soil quality [14]-[18].

The 30-ton $\mathrm{ha}^{-1}$ compost application gives the highest yield of fresh weight of red chili [19]. The highest fresh weight of red chili was obtained from biochar treatment from cow dung at a dose of 10-tons ha ${ }^{-1}$, significantly different and increased by $28.63 \%$ compared without biochar [20]. The chicken manure 2 tons/ha application can increase corn production by $6 \%$ in the first season, while the second season by $40 \%$ [21]. While the research results [22] the provision of chicken manure is better than cow and goat manure in vegetable and lettuce plants in Andosol Cisarua soil. The purpose of this study was to examine the quality of several types of manure as raw material for composting and biochar applied to the soil-on-soil properties, and its effect on the number of fruits and weight of fresh red chili.

\section{MATERIAL AND METHOD}

\section{A. Analysis of Livestock Manure Characteristics}

Before composting, each animal waste (cow, goat, and chicken) is tested with laboratory analysis to determine nutrition content. The results of the analysis test are shown in Table 1.

TABLE I

CHARACTERISTICS OF NUTRIENT CONTENT OF MANURE ORIGINATING FROM COW, GOAT AND CHICKEN FAECES [9]

\begin{tabular}{cccc}
\hline \multirow{2}{*}{ Type of Analysis } & \multicolumn{3}{c}{ Manure } \\
\cline { 2 - 4 } & Cow & Goat & Chicken \\
\hline C organic (\%) & 26.86 & 30.14 & 26.16 \\
N-total (\%) & 0.67 & 0.54 & 1.83 \\
C/N & 40.09 & 55.81 & 14.30 \\
P-available (ppm) & 504.46 & 860.04 & 654.22 \\
K-available (ppm) & 368.90 & 365.25 & 362.50 \\
\hline
\end{tabular}

\section{B. Compost Manufacturing}

TABLE II

Characteristics of COW, GOAT AND CHICKEn MANuRE COMPOST [9]

\begin{tabular}{cccc}
\hline \multirow{2}{*}{ Type of Analysis } & \multicolumn{3}{c}{ Compost } \\
\cline { 2 - 4 } & Cow & Goat & Chicken \\
\hline C organic (\%) & 12.89 & 29.66 & 17.44 \\
N (\%) & 0.78 & 0.56 & 0.43 \\
C/N & 16.53 & 52.96 & 40.56 \\
P (ppm) & 422.68 & 746.74 & 782.62 \\
K (ppm) & 366.80 & 364.90 & 368.70 \\
\hline
\end{tabular}


Each manure was composted consisting of manure (80\%), rice husk (10\%), Gamal leaves (5\%), husk ash/kitchen ash $(5 \%)$, agricultural lime $(1 \%)$, molasses $(100 \mathrm{ml})$ and EM-4 $(100 \mathrm{ml})$ fermenters. The composting process is carried out for three weeks. Compost analysis test results are shown in Table 2.

\section{Biochar Manufacturing}

Biochar is made in a simple way through coaxing on a pan made from used drum flats. Each livestock faeces as much as $100 \mathrm{~kg}$ is carried out burning 1-2 hours, then cooled to obtain a $30-60 \%$ yield range. Biochar analysis results of cow, goat, and chicken faeces are shown in Table 3.

TABLE III

BIOCHAR CHARACTERISTICS OF COW, GOAT, AND CHICKEN MANURE [9]

\begin{tabular}{cccc}
\hline \multirow{2}{*}{ Type of Analysis } & \multicolumn{3}{c}{ Biochar } \\
\cline { 2 - 4 } & Cow & Goat & Chicken \\
\hline C organic (\%) & 28.82 & 22.39 & 24.07 \\
N (\%) & 0.14 & 0.19 & 0.16 \\
C/N & 205.86 & 117.84 & 150.44 \\
P (ppm) & 383.09 & 420.62 & 391.04 \\
K (ppm) & 159.64 & 175.20 & 232.36 \\
\hline
\end{tabular}

\section{Research Design}

This research was conducted in the Selat Village, Abiansemal District, Badung Regency, Bali. Analysis of soil properties before and after the study was conducted at the Soil Laboratory of the Faculty of Agriculture, Udayana University, Denpasar. The study was conducted in a greenhouse using polybags, which lasted from April to August 2019. This research was a nested experiment using a randomized block design. The treatment composition consisted of 6 types of fertilizer: Cow Compost (Cc), Goat Compost (Gc), Chicken Compost (Ckc), Cow Biochar (Cb), Goat Biochar (Gb), Chicken Biochar (Ckb), and three levels of fertilizer dosage $\left(5,10\right.$, and 15-tons $\left.\mathrm{ha}^{-1}\right)$ and one control treatment. From the treatments' arrangement, 19 treatments were obtained, using 3 replications, a total of 57 experimental units were needed.

\section{E. Observation Variable}

The observed variables are the soil properties after the study (C-organic, N-total, P-available, K-available, and C/N), and the observed plant variables are the amount of fresh red chili per plant and the weight of fresh red chili per plant.

\section{RESULTS AND DISCUSSION}

The statistical test results in Table 4, show that the differences in the types of compost fertilizer differed significantly $(\mathrm{P}<0.05)$ with $\mathrm{N}$-total and weight of red chili, and were significantly different $(\mathrm{P}<0.05)$ against $\mathrm{P}$-available. This result shows that differences in livestock manure sources (cattle, goats, and chickens) for compost affect soil properties and chili yields. Goats' eating behavior as a browser consumes more leaves so that the $\mathrm{P}$ content is higher (Table 1). While the highest $\mathrm{N}$-amount in chicken manure, because the ration consumed is more than whole grains, so it is not perfectly digested in the digestive tract. Whereas after being processed into compost, N-total in compost from cow dung is highest because of the presence of microbes that multiply in the cecum and large intestine and develop during the composting process, but the $\mathrm{P}$ available is the lowest (Table 2). Although the type of livestock manure raw material in compost and biochar does not affect the amount of red chili per plant, this type of fertilizer has a significant effect on the weight of red chili per plant.

TABLE IV

SIGNIFICANCE OF THE EFFECT OF TYPES AND DOSES OF BIOCHAR AND COMPOST ON VARIABLE SOIL PROPERTIES AND Y IELD OF RED CHILI

\begin{tabular}{|c|c|c|c|c|c|c|c|c|}
\hline \multirow{2}{*}{ No } & \multirow{2}{*}{ Variable } & \multirow{2}{*}{$\begin{array}{c}\text { Type } \\
\text { of } \\
\text { fertilizer }\end{array}$} & \multicolumn{6}{|c|}{ Dosage } \\
\hline & & & $\mathrm{Cc}$ & Gc & Ckc & $\mathbf{C b}$ & Gb & Ckb \\
\hline 1. & C-organic (\%) & ns & ns & $* *$ & ns & ns & ns & ns \\
\hline 2. & N-total (\%) & $*$ & ns & $\mathrm{ns}$ & $*$ & ns & $\mathrm{ns}$ & $* *$ \\
\hline 3. & P-available (ppm) & $* *$ & $\mathrm{~ns}$ & $* *$ & $* *$ & $* *$ & $* *$ & $* *$ \\
\hline 4. & K-available (ppm) & ns & $* *$ & $*$ & $* *$ & ns & $* *$ & ns \\
\hline 5. & Rasio $\mathrm{C} / \mathrm{N}$ & ns & ns & $\mathrm{ns}$ & ns & ns & ns & ns \\
\hline 6. & $\begin{array}{l}\text { Number of red } \\
\text { chilies (fruit) }\end{array}$ & ns & $\mathrm{ns}$ & $\mathrm{ns}$ & ns & ns & ns & $*$ \\
\hline 7. & $\begin{array}{l}\text { Weight of fresh } \\
\text { red chili }(\mathrm{g})\end{array}$ & $*$ & ns & $\mathrm{ns}$ & ns & ns & $\mathrm{ns}$ & $* *$ \\
\hline
\end{tabular}

TABLE V

EFFECT OF COMPOST AND BIOCHAR FERTILIZER ON SOIL PROPERTIES AND YIELD OF RED CHILI

\begin{tabular}{cccccccc}
\hline $\begin{array}{c}\text { Type of } \\
\text { Fertilizer }\end{array}$ & $\begin{array}{c}\mathbf{C} \\
\text { organic } \\
(\mathbf{\%})\end{array}$ & $\begin{array}{c}\mathbf{N} \\
\text { total } \\
(\%)\end{array}$ & $\begin{array}{c}\mathbf{P} \\
\text { available } \\
(\mathbf{p p m})\end{array}$ & $\begin{array}{c}\mathbf{K} \\
\text { available } \\
(\mathbf{p p m})\end{array}$ & $\mathbf{C} / \mathbf{N}$ & $\begin{array}{c}\text { Number of } \\
\text { red chillies } \\
\text { (fruit) }\end{array}$ & $\begin{array}{c}\text { Weight of } \\
\text { fresh red chilli } \\
(\mathbf{g})\end{array}$ \\
\hline Cow Compost $(\mathrm{Cc})$ & $2.95 \mathrm{a}$ & $0.14 \mathrm{c}$ & $75.03 \mathrm{c}$ & $181.12 \mathrm{a}$ & $20.95 \mathrm{a}$ & $17.67 \mathrm{~b}$ & $143.86 \mathrm{~b}$ \\
Goat Compost $(\mathrm{Gc})$ & $3.56 \mathrm{a}$ & $0.18 \mathrm{abc}$ & $132.72 \mathrm{~b}$ & $182.18 \mathrm{a}$ & $20.51 \mathrm{a}$ & $20.75 \mathrm{ab}$ & $168.37 \mathrm{ab}$ \\
Chicken Compost $(\mathrm{Ckc})$ & $3.18 \mathrm{a}$ & $0.21 \mathrm{a}$ & $153.63 \mathrm{~b}$ & $182.51 \mathrm{a}$ & $16.28 \mathrm{a}$ & $18.33 \mathrm{ab}$ & $156.80 \mathrm{ab}$ \\
Cow Biochar $(\mathrm{Cb})$ & $3.07 \mathrm{a}$ & $0.16 \mathrm{abc}$ & $141.54 \mathrm{~b}$ & $174.25 \mathrm{a}$ & $20.52 \mathrm{a}$ & $19.42 \mathrm{ab}$ & $158.22 \mathrm{ab}$ \\
Goat Biochar $(\mathrm{Gb})$ & $3.51 \mathrm{a}$ & $0.15 \mathrm{bc}$ & $127.87 \mathrm{~b}$ & $184.75 \mathrm{a}$ & $25.23 \mathrm{a}$ & $18.75 \mathrm{ab}$ & $163.79 \mathrm{ab}$ \\
Chicken Biochar $(\mathrm{Ckb})$ & $3.08 \mathrm{a}$ & $0.20 \mathrm{ab}$ & $271.13 \mathrm{a}$ & $171.93 \mathrm{a}$ & $16.27 \mathrm{a}$ & $21.42 \mathrm{a}$ & $188.74 \mathrm{a}$ \\
Coefficient of Variant & $24.94 \%$ & $23.96 \%$ & $18.30 \%$ & $7.16 \%$ & $27.05 \%$ & $18.65 \%$ & $18.87 \%$ \\
\hline
\end{tabular}

\footnotetext{
Information: The same letter at the average value in the same column is not significantly different at the Duncan test level of $5 \%$
} 
Figures 1, 2, 3, 4, and 5 presents the effect of various types of fertilizer treatment on soil properties such as N, P, $\mathrm{K}, \mathrm{C} / \mathrm{N}$, and fresh weight of red chili. In detail, in Table 5 compost from chicken manure has the highest $\mathrm{N}$ and $\mathrm{P}$ content (Figure 1, 2) significantly different $(\mathrm{P}<0.05)$ compared to cow dung compost, but the available $\mathrm{K}$ is not significantly different (Figure 3). Potassium and Calcium (part of plant cell walls) show positive deviation when composted. While the $\mathrm{C} / \mathrm{N}$ ratio (Figure 4) is lower than cow dung compost, but it is not significantly different $(\mathrm{P}>0.05)$, and is still in a good range [6].

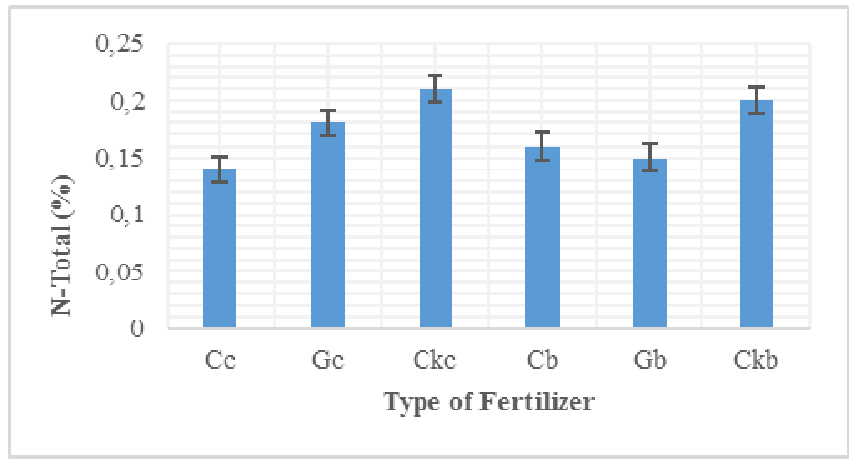

Fig. 1 Relationship between the type of fertilizer with N-total



Fig. 2 Relationship between the type of fertilizer with P-available

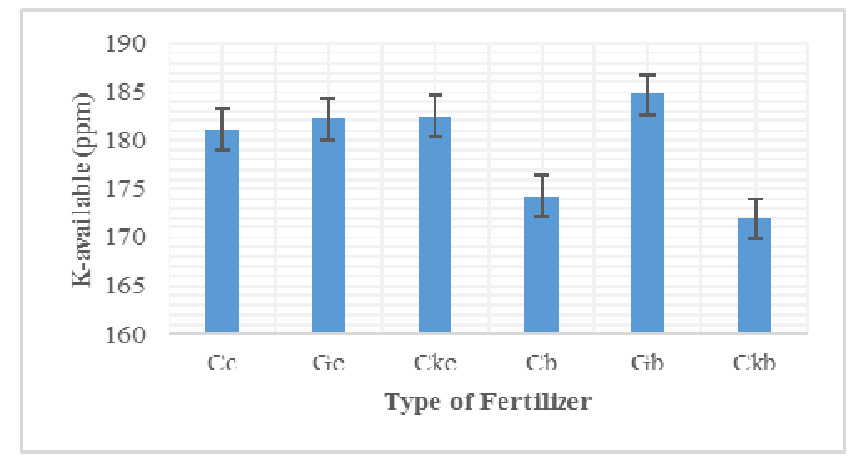

Fig. 3 Relationship between the type of fertilizer with K-available

Biochar treatment from chicken manure gave the highest yield on fresh chili weight variables than other types of fertilizer treatments (Figure 5). This result proves that goats consume more legume leaves and, in the cecum, and large intestine of living bacteria so that manure contains a lot of $\mathrm{N}$, then after decomposition $\mathrm{N}$ is available in more soil. Besides, with the hard physical structure of goat faeces, the nutrient elements bound in it are not easily washed away dissolved in water.

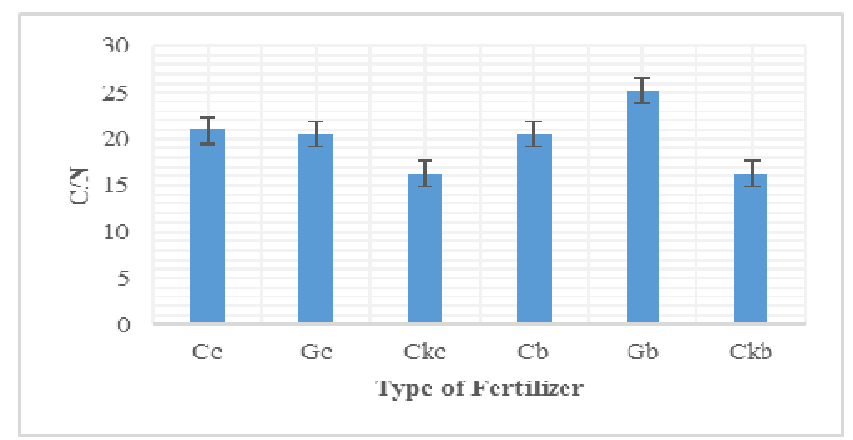

Fig. 4 Relationship between the type of fertilizer with $\mathrm{C} / \mathrm{N}$ ratio

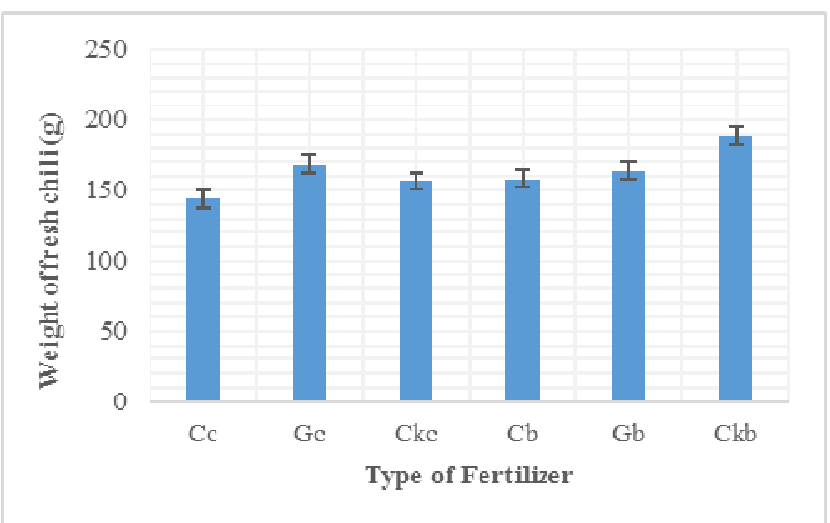

Fig. 5 Relationship between the type of fertilizer with the weight of fresh chili

Whereas, chicken biochar manure was significantly (P $<0.05$ ) highest for fresh red chili per plant and the weight of fresh red chili per plant, and this is because of the highest total $\mathrm{N}$ and $\mathrm{P}$, and the lowest $\mathrm{C} / \mathrm{N}$ in poultry biochar droppings. Corn production increased by $6 \%$ in the first season [21]. Chicken manure fertilizer is better than a goat and goat manure in vegetable crops [22]. Poultry droppings are among the best-performing organic fertilizers and are therefore recommended for farmers in agro-climatic conditions compared to other livestock compost on the number of branch leaves, leaf area, and speed of harvest time on coriander plants [23].

Compost from cow dung responds to the lowest amount of fresh red chili per plant and the lowest weight of fresh red chili per plant $(\mathrm{P}<0.05)$, because of the lowest amount of $\mathrm{N}$ and $\mathrm{P}$ available and the highest $\mathrm{C} / \mathrm{N}$. This finding is also related to the predominant consumption of fodder field grass and elephant grass [24], where field grass contains high crude fiber, which consequently will increase the $\mathrm{C} / \mathrm{N}$ ratio. Higher $\mathrm{C} / \mathrm{N}$ ratios cause high $\mathrm{C}$ levels to suppress plant growth because microbial decomposers will use available $\mathrm{N}$ to decompose organic matter so that plants lack $\mathrm{N}$ [6]. The fermentation process in processing cow dung into biological fertilizer affects the $\mathrm{pH}$ decrease from 8.13 to 6.77 and can eliminate pathogenic microorganisms at $50{ }^{\circ} \mathrm{C}$ [25]. Seasonal differences also affect the quality of animal feed, were in the dry season the composition of field grass in the ration increases [26], consequently, the higher the crude fiber, the higher $\mathrm{C} / \mathrm{N}$. 
TABLE VI

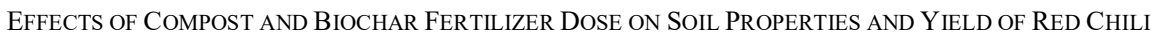

\begin{tabular}{|c|c|c|c|c|c|c|c|}
\hline $\begin{array}{c}\text { Dose } \\
\text { Treatment }\end{array}$ & $\begin{array}{c}\text { C } \\
\text { organic } \\
(\%)\end{array}$ & $\begin{array}{c}\mathrm{N} \\
\text { total } \\
(\%)\end{array}$ & $\begin{array}{c}\mathbf{P} \\
\text { available } \\
(\mathrm{ppm})\end{array}$ & $\begin{array}{c}\mathbf{K} \\
\text { available } \\
(\mathrm{ppm})\end{array}$ & $\mathbf{C} / \mathbf{N}$ & $\begin{array}{l}\text { Number of red } \\
\text { chilies per plant } \\
\text { (fruit) }\end{array}$ & $\begin{array}{l}\text { Weight of fresh } \\
\text { red chili per plant } \\
(\mathrm{g})\end{array}$ \\
\hline CcD0 & $2.09 \mathrm{a}$ & $0.13 \mathrm{a}$ & $59.55 \mathrm{a}$ & $162.97 \mathrm{~b}$ & $16.73 \mathrm{a}$ & $16.33 \mathrm{a}$ & $137.49 \mathrm{a}$ \\
\hline $\mathrm{CcD} 1$ & $2.47 \mathrm{a}$ & $0.15 \mathrm{a}$ & $71.71 \mathrm{a}$ & $169.71 \mathrm{~b}$ & $17.33 \mathrm{a}$ & $18.00 \mathrm{a}$ & $144.28 \mathrm{a}$ \\
\hline $\mathrm{CcD} 2$ & $3.38 \mathrm{a}$ & $0.15 \mathrm{a}$ & $84.94 \mathrm{a}$ & $207.18 \mathrm{a}$ & $22.88 \mathrm{a}$ & $18.67 \mathrm{a}$ & $150.38 \mathrm{a}$ \\
\hline $\mathrm{CcD} 3$ & $3.87 \mathrm{a}$ & $0.15 \mathrm{a}$ & $83.93 \mathrm{a}$ & $184.62 \mathrm{ab}$ & $26.88 \mathrm{a}$ & $17.67 \mathrm{a}$ & $143.27 \mathrm{a}$ \\
\hline GcD0 & $2.09 \mathrm{~b}$ & $0.13 \mathrm{a}$ & $59.55 \mathrm{c}$ & $162.97 \mathrm{~b}$ & $16.73 \mathrm{a}$ & $16.33 \mathrm{a}$ & $137.49 \mathrm{a}$ \\
\hline GcD1 & $3.36 \mathrm{~b}$ & $0.16 \mathrm{a}$ & $106.57 \mathrm{bc}$ & $178.46 \mathrm{~b}$ & $20.83 \mathrm{a}$ & $24.00 \mathrm{a}$ & $172.20 \mathrm{a}$ \\
\hline $\mathrm{GcD} 2$ & $3.55 \mathrm{~b}$ & $0.22 \mathrm{a}$ & $138.24 \mathrm{~b}$ & $180.38 \mathrm{~b}$ & $16.40 \mathrm{a}$ & $22.67 \mathrm{a}$ & $189.95 \mathrm{a}$ \\
\hline GcD3 & $5.26 \mathrm{a}$ & $0.20 \mathrm{a}$ & $226.52 \mathrm{a}$ & $206.93 \mathrm{a}$ & $28.09 \mathrm{a}$ & $20.00 \mathrm{a}$ & $173.84 \mathrm{a}$ \\
\hline $\mathrm{CkcD0}$ & $2.09 \mathrm{a}$ & $0.13 \mathrm{c}$ & $59.55 \mathrm{c}$ & $162.97 \mathrm{~b}$ & $16.73 \mathrm{a}$ & $16.33 \mathrm{a}$ & $137.49 \mathrm{a}$ \\
\hline CkcD1 & $3.45 \mathrm{a}$ & $0.20 \mathrm{abc}$ & $179.31 \mathrm{~b}$ & $210.08 \mathrm{a}$ & $18.25 \mathrm{a}$ & $18.00 \mathrm{a}$ & $173.67 \mathrm{a}$ \\
\hline $\mathrm{CkcD} 2$ & $3.50 \mathrm{a}$ & $0.26 \mathrm{a}$ & $128.90 \mathrm{~b}$ & $183.22 \mathrm{~b}$ & $13.46 \mathrm{a}$ & $18.67 \mathrm{a}$ & $141.36 \mathrm{a}$ \\
\hline $\mathrm{CkcD} 3$ & $3.66 \mathrm{a}$ & $0.25 \mathrm{ab}$ & $246.77 \mathrm{a}$ & $173.78 \mathrm{~b}$ & $16.69 \mathrm{a}$ & $20.33 \mathrm{a}$ & $174.68 \mathrm{a}$ \\
\hline CbD0 & $2.09 \mathrm{a}$ & $0.13 \mathrm{a}$ & $59.55 \mathrm{c}$ & $162.97 \mathrm{a}$ & $16.73 \mathrm{a}$ & $16.33 \mathrm{a}$ & $137.49 \mathrm{a}$ \\
\hline $\mathrm{CbD} 1$ & $3.00 \mathrm{a}$ & $0.15 \mathrm{a}$ & 95.48 bc & $181.22 \mathrm{a}$ & $20.05 \mathrm{a}$ & $18.33 \mathrm{a}$ & $149.05 \mathrm{a}$ \\
\hline $\mathrm{CbD} 2$ & $3.30 \mathrm{a}$ & $0.17 \mathrm{a}$ & $187.69 \mathrm{a}$ & $177.71 \mathrm{a}$ & $21.86 \mathrm{a}$ & $23.67 \mathrm{a}$ & $197.92 \mathrm{a}$ \\
\hline CbD3 & $3.89 \mathrm{a}$ & $0.19 \mathrm{a}$ & $223.42 \mathrm{a}$ & $175.10 \mathrm{a}$ & $23.43 \mathrm{a}$ & $19.33 \mathrm{a}$ & $148.42 \mathrm{a}$ \\
\hline GbD0 & $2.09 \mathrm{a}$ & $0.13 \mathrm{a}$ & $59.55 \mathrm{c}$ & $162.97 \mathrm{c}$ & $16.73 \mathrm{a}$ & $16.33 \mathrm{a}$ & $137.49 \mathrm{a}$ \\
\hline GbD1 & $3.85 \mathrm{a}$ & $0.15 \mathrm{a}$ & 88.69 bc & $167.79 \mathrm{bc}$ & $26.08 \mathrm{a}$ & $19.67 \mathrm{a}$ & $182.10 \mathrm{a}$ \\
\hline GbD2 & $4.04 \mathrm{a}$ & $0.15 \mathrm{a}$ & $137.74 \mathrm{~b}$ & $194.90 \mathrm{ab}$ & $30.61 \mathrm{a}$ & $21.00 \mathrm{a}$ & $183.01 \mathrm{a}$ \\
\hline GbD3 & $4.07 \mathrm{a}$ & $0.19 \mathrm{a}$ & $225.48 \mathrm{a}$ & $213.33 \mathrm{a}$ & $27.47 \mathrm{a}$ & $18.00 \mathrm{a}$ & $152.54 \mathrm{a}$ \\
\hline CkbD0 & $2.09 \mathrm{a}$ & $0.13 \mathrm{c}$ & $59.55 \mathrm{~d}$ & $162.97 \mathrm{a}$ & $16.73 \mathrm{a}$ & $16.33 \mathrm{~b}$ & $137.49 \mathrm{~b}$ \\
\hline CkbD1 & $3.24 \mathrm{a}$ & $0.16 \mathrm{bc}$ & $217.94 \mathrm{c}$ & $189.30 \mathrm{a}$ & $20.98 \mathrm{a}$ & $23.33 \mathrm{ab}$ & $200.81 \mathrm{ab}$ \\
\hline CkbD2 & $3.57 \mathrm{a}$ & $0.27 \mathrm{a}$ & $329.16 \mathrm{~b}$ & $169.38 \mathrm{a}$ & $13.41 \mathrm{a}$ & $21.00 \mathrm{abc}$ & $183.35 \mathrm{abc}$ \\
\hline CkbD3 & $3.44 \mathrm{a}$ & $0.25 \mathrm{a}$ & $477.87 \mathrm{a}$ & $166.07 \mathrm{a}$ & $13.95 \mathrm{a}$ & $25.00 \mathrm{a}$ & $233.31 \mathrm{a}$ \\
\hline
\end{tabular}

Information:

- The same letter at the average value in the same column is not significantly different at the Duncan test level of 5\%

- Cow Compost (Cc), Goat Compost (Gc), Chicken Compost (Ckc), Cow Biochar (Cb), Goat Biochar (Gb), Chicken Biochar (Ckb), 0-ton ha-1 (D0), 5 ton ha-1 (D1), 10 ton ha-1 (D2), 15 ton ha-1 (D3).

The low number of fresh red chilies and the weight of fresh red chilies per plant, especially in soils that are composted with cow compost, are due to the low $\mathrm{N}$ and the available $\mathrm{P}$ levels $\mathrm{K}$ available in the soil. In photosynthesis, the $\mathrm{N}$ element functions in leaf formation, while the $\mathrm{P}$ and $\mathrm{K}$ elements function in the growth of stems, branches, and roots. The more leaf formation and the better the growth of stems and roots, the more fruit formation. Likewise, when viewed from the biochar quality of chicken manure significantly the highest number of fruits and the weight of chili fruit, due to the highest amount of elements $\mathrm{N}$ and $\mathrm{P}$ found in the soil.

When viewed from compost doses and biochar fertilizers, in general, they have a significant effect on soil properties such as $\mathrm{N}, \mathrm{P}, \mathrm{K}$, except $\mathrm{C} / \mathrm{N}$ which are not significantly different (Tables 4 and 6). Likewise, the amount of fresh chili per plant and the weight of fresh chili per plant appears to have a significant effect, but the increase in chicken compost dose responds to the number of fresh red chili per plant, and the weight of red chili per plant is increasing, because it significantly causes improvements in the properties. land such as total N, P and K available in the soil.
Similar conditions were also shown by biochar from chicken manure and were significantly higher than controls. This finding also proves that compost of chicken manure and biochar chicken manure is better than cow dung or goat manure.

There were no significant differences in the total doses of cattle and goat compost dose to the variable $\mathrm{C} / \mathrm{N}$ ratio and the number of chilies and weight of red chilies per plant. However, the only P variable available in the compost of goat manure was significantly different. While the compost dose of chicken manure there is a significant difference in soil properties both the total content of $\mathrm{N}, \mathrm{P}$ available, and $\mathrm{K}$ available in the soil, but there is no significant effect on the number of fruits and the weight of fresh red chili. In contrast to the biochar dosage of cow, goat, and chicken manure, there is no significant difference from the total $\mathrm{N}$, because, during the combustion process in the production of organic biochar elements, especially proteins undergo evaporation. Only P is available in the soil, especially chicken manure, the more highly significant doses, the higher. As a result, the number of fruits and the weight of fresh red chili per plant also differed significantly. Animal manure and chicken 
manure have different effects on changes in soil properties, especially $\mathrm{K}$ variable, plant biomass production and root distribution in tropical soils [27]. The use of bio-organic fertilizer in the soil can reduce pathogenic bacteria's development and reduce the incidence of disease in plants [28].

\section{CONCLUSION}

Type of livestock manure raw material for making compost and biochar influences soil properties and production of fresh red chili per plant and the weight of fresh red chili per plant. Compost from goat manure is best, while biochar from chicken manure is best. The higher the dosage of chicken manure compost, the better, and the higher biochar dose significantly increases the number of fresh red chilies per plant and the weight of fresh red chili per plant.

\section{ACKNOWLEDGEMENT}

We thank the reviewers for their corrections for the published my paper, and the research team and Sari Sedana livestock group for their assistance and support during the research process.

\section{REFERENCES}

[1] Ye, L., Zhao, X., Bao, E., Li, J., Zou, Z., and Cao, K. 2020. Bioorganic fertilizer with reduced rates of chemical fertilization improves soil fertility and enhances tomato yield and quality. Scientific Reports, 10(1), 1-11.

[2] Sudita, I. D. N., Suariani, Y. T. L., Kaca, I. N., and Yudiastari, N. M. 2018. The effectiveness of "Simantri" program in producing organic fertilizer and biourine to organic farming system in Bali, Indonesia. MATEC Web of Conferences 197; 13002. EDP Sciences.

[3] Kurnia, U., Setyorini D., Prihatini T., Sutono S., dan Suganda, H. 2001. Perkembangan dan penggunaan pupuk oraganik di Indonesia. Direktorat Pupuk dan Pestisida. Direktorat Jendral Bina Sarana Pertanian. Jakarta. Nopember 2001 (tidak dipublikasikan).

[4] Garcia C, Hemandez T, Costa F, Ceccanti B. 1994. Biochemical parameters in soil generated by the addition of organic waste. Wastes Management and Res. 12: 457-466.

[5] Li, S., Li, J., Zhang, B., Li, D., Li, G., and Li, Y. 2017. Effect of different organic fertilizers application on growth and environmental risk of nitrate under a vegetable field. Scientific reports, 7(1), 1-9.

[6] Hartatik, W. and Widowati, L. R. 2006. Pupuk Kandang. Pupuk Organik dan Pupuk Hayati. Balai Besar Litbang Sumberdaya Lahan Pertanian, Badan Penelitian dan Pengembangan Pertanian.

[7] Setyorini, D., Saraswati, R. dan Anwar, E. K. 2006. Kompos. Pupuk Organik dan Pupuk Hayati. Balai Besar Penelitian Pengembangan Sumberdaya Lahan Pertanian, Bogor. Hal.11-40

[8] Tan, K. H. 1991. Principle of Soil Chemistry (Dasar-Dasar Kimia Tanah) (Alih bahasa: Didiek Hadjar Goenardi) Gadjah Mada University Press. Yogyakarta. p, 295.

[9] Situmeang, Y. P., Sudita, I D N., and Suarta, M. 2019. Manure Utilization from Cows, Goats, and Chickens as Compost, Biochar, and Poschar in Increasing the Red Chili Yield. International Journal on Advanced Science, Engineering, and Information Technology 9(6), 2188-2095.

[10] Lin, W., Lin, M., Zhou, H., Wu, H., Li, Z., and Lin, W. 2019. The effects of chemical and organic fertilizer usage on rhizosphere soil in tea orchards. PloS one, 14(5).

[11] Abera, T., Tufa, T., Midega, T., Kumbi, H., and Tola, B. 2018. Effect of integrated inorganic and organic fertilizers on yield and yield components of Barley in Liben Jawi District. Hindawi, International Journal of Agronomy, 2018.

[12] Sutanto, R. 2002. Pertanian Organik: Menuju Pertanian Alternatif dan berkelanjutan. Penerbit Kanisius. Jogyakarta.

[13] Bambang SA 2012. Si Hitam Biochar yang Multiguna. PT. Perkebunan Nusantara X (Persero), Surabaya

[14] Harsanti, E. S. dan Ardiwinata, A. N. 2011. Arang aktif meningkatkan kualitas lingkungan. Agritani Edisi, 6-12.

[15] Putra, IGLAAA, Situmeang, Y.P., Yuliartini, M.S., and Udayana, I.G.B. 2019. Application of biochar and compost to changes in physical and chemical properties of soil and corn yield on dry land. In Journal of Physics: Conference Series (Vol. 1402, No. 5, p. 055029). IOP Publishing

[16] Situmeang Y. P., Adnyana I M., Subadiyasa I N. N., and Merit I N. 2018. Effectiveness of bamboo biochar combined with compost and NPK fertilizer to improved soil quality and corn yield. International Journal on Advanced Science, Engineering, and Information Technology, 8(5), 2241-2248.

[17] Pavlíková, D., Zemanova, V., Břendová, K., Kubatova, P., and Tlustoš, P. 2017. Effect of biochar application on the content of nutrients $(\mathrm{Ca}, \mathrm{Fe}, \mathrm{K}, \mathrm{Mg}, \mathrm{Na}, \mathrm{P})$ and amino acids in subsequently growing spinach and mustard. Plant, Soil and Environment, 63(7), 322-327.

[18] Situmeang, Y. P. 2018. Soil quality in corn cultivation using bamboo biochar, compost, and phonska. In MATEC Web of Conferences (Vol. 197, p. 13001). EDP Sciences.

[19] Amaral, H. D. D. R., Situmeang, Y. P., and Suarta, M. 2019. The effects of compost and biochar on the growth and yield of red chili plants. Journal of Physics: Conference Series 1402 (3) 033057.

[20] Dapa, D. S., Situmeang, Y. P., and Sudewa, K. A. 2020. The Use of Biochar from Cow Feces and Bioboost in The Red Chili Plant (Capsicum annum L.). SEAS (Sustainable Environment Agricultural Science), 3(2), 118-123.

[21] Sutriadi, M.T., Hidayat, R., Rochayati, dan Setyorini, D. 2005. Ameliorasi lahan dengan fosfat alami untuk perbaikan kesuburan tanah kering masam Typic Hapludox di Kalimantan Selatan. Proceding Seminar Nasional Inovasi Teknologi Sumber Daya Tanah dan Iklim. Pusat Penelitian dan Pengembangan Tanah dan Agroklimit, Bogor.

[22] Widowati L.R., Widiati, S dan Setyorini, D. 2004. Karakterisasi Pupuk Organik dan Pupuk Hayati yang Efektif untuk Budidaya Sayuran Organik. Laporan Proyek Penelitian Program Pengembangan Agribisnis, Balai Penelitian Tanah.

[23] Ahmad, T., Syed, T.S., Ullah, F., Ghafoor, F., and Anwar, U. 2017. Effect of organic fertilizers on growth and yield of coriander. International Journal of Agricultural and Environmental Research (IJAER). 3(1): 116-120

[24] Sudita, I. D. N., Mahardika, I. G., Suarna, I. W., and Partama, I. G. 2015. Analysis of feed for digestibility bali cow in group" Simantri" program in Bali on different topographic. International Journal on Advanced Science, Engineering, and Information Technology, 5(6), 495-500.

[25] Hamouda, R., Bahnasawy, A., \& Ali, S. Ramadan ElS 2016. Some Physical and Chemical Properties of Bio-fertilizers. J Fertil Pestic, 7(161), 2.

[26] Sudita, I. D. N. 2019. Nutrient fulfilling status for bali cows in Bali, Indonesia in season differences. Journal of Physics: Conference Series 1402 (3) 033062. IOP Publishing.

[27] Ahmad, A. A., Radovich, T. J., Nguyen, H. V., Uyeda, J., Arakaki, A., Cadby, J., ... and Teves, G. 2016. Use of organic fertilizers to enhance soil fertility, plant growth, and yield in a tropical environment. Organic Fertilizers-From Basic Concepts to Applied Outcomes, 85108.

[28] Luo, J., Ran, W., Hu, J., Yang, X., Xu, Y., and Shen, Q. 2010. Application of Bio-Organic Fertilizer Significantly Affected Fungal Diversity of Soils. Soil Science Society of America Journal (SSSAJ), 74 (6), 2039-2048. 